\title{
Bioactive Indole Diketopiperazine Alkaloids from the Marine Endophytic Fungus Aspergillus sp. YJ191021
}

\author{
Jin Yang ${ }^{1}$, Lizhi Gong ${ }^{1}$, Miaomiao Guo ${ }^{2}$, Yu Jiang ${ }^{1}$, Yi Ding ${ }^{1}$, Zhijie Wang ${ }^{1}$, Xiujuan Xin ${ }^{1}$ and Faliang An ${ }^{1, *(1)}$ \\ 1 Key Laboratory of Bioreactor Engineering, East China University of Science and Technology, \\ 130 Meilong Road, Shanghai 200237, China; ecustyangjin@163.com (J.Y.); 15216603669@163.com (L.G.); \\ jy15663497239@163.com (Y.J.); zjzsdy@163.com (Y.D.); wang56560273@163.com (Z.W.); \\ xinxj@ecust.edu.cn (X.X.) \\ 2 Key Laboratory of Cosmetic, Beijing Technology and Business University, China National Light Industry, \\ 33 Fucheng Road, Beijing 100048, China; guomiaomiao7@163.com \\ * Correspondence: flan2016@ecust.edu.cn; Tel.: +86-21-6425-1185
}

Citation: Yang, J.; Gong, L.; Guo, M.; Jiang, Y.; Ding, Y.; Wang, Z.; Xin, X.; An, F. Bioactive Indole

Diketopiperazine Alkaloids from the Marine Endophytic Fungus Aspergillus sp. YJ191021. Mar. Drugs 2021, 19, 157. https://doi.org/ $10.3390 / \mathrm{md} 19030157$

Academic Editors: Bin Wu and Ikuro Abe

Received: 23 February 2021

Accepted: 16 March 2021

Published: 17 March 2021

Publisher's Note: MDPI stays neutral with regard to jurisdictional claims in published maps and institutional affiliations.

Copyright: (C) 2021 by the authors. Licensee MDPI, Basel, Switzerland. This article is an open access article distributed under the terms and conditions of the Creative Commons Attribution (CC BY) license (https:// creativecommons.org/licenses/by/ $4.0 /)$.

\begin{abstract}
Six new prenylated indole diketopiperazine alkaloids, asperthrins A-F (1-6), along with eight known analogues (7-14), were isolated from the marine-derived endophytic fungus Aspergillus sp. YJ191021. Their planar structures and absolute configurations were elucidated by HR-ESI-MS, 1D/2D NMR data, and time-dependent density functional theory (TDDFT)/ECD calculation. The isolated compounds were assayed for their inhibition against three agricultural pathogenic fungi, four fish pathogenic bacteria, and two agricultural pathogenic bacteria. Compound 1 exhibited moderate antifungal and antibacterial activities against Vibrio anguillarum, Xanthomonas oryzae pv. Oryzicola, and Rhizoctonia solani with minimal inhibitory concentration (MIC) values of 8, 12.5, and $25 \mu \mathrm{g} / \mathrm{mL}$, respectively. Furthermore, 1 displayed notable anti-inflammatory activity with $\mathrm{IC}_{50}$ value of $1.46 \pm 0.21 \mu \mathrm{M}$ in Propionibacterium acnes induced human monocyte cell line (THP-1).
\end{abstract}

Keywords: indole diketopiperazine alkaloids; endophytic fungus; Aspergillus sp.; antimicrobial

\section{Introduction}

Endophytic fungi refer to microorganisms that spend their entire or part of their life cycle in plant tissues, animals, and environments without causing any obvious infection or visible disease to the host [1]. Endophytic fungi are prolific microbial resources for the production ability of many biologically active secondary metabolites, which can help the host to resist pathogenic microorganisms [2]. Various endophytic fungi have drawn substantial attention due to their potential to produce chemically diverse and biologically active secondary metabolites with anti-cancer, anti-microbial, anti-viral, and insecticidal activities [3-6]. In our continuous searching for novel bioactive secondary metabolites from marine endophytic fungi [7-9], the Aspergillus sp. YJ191021 attracted our attention, not only for the characteristic indole diketopiperazine ultraviolet (UV) absorptions of the crude extracts, but also for their potent antimicrobial activities against agricultural pathogenic fungi.

Diketopiperazine alkaloids are valued not only for their properties and functions in fungal self-biology, but also for niche establishment to defend abiotic and biotic stress in nature. They are cyclodipeptides formed by condensation of two amino acids under the control of NRPS genes [10], especially those isolated from the genera Aspergillus and Penicillium [11]. Among them, those derived from tryptophan and proline are the most popular types in the current study, especially in structural diversity, chemical synthesis, and pharmacological activity [12-14]. Besides, the substitution of the isopentenyl group enriches the variability of their structures. Prenylated indole alkaloids have been reported to show a wide array of biological activities including antimicrobial, insecticidal, and cytotoxic activities $[14,15]$. The fascinating structural and biological properties of prenylated indole alkaloids make it possible for them to be developed into our armor and weaponry: Natural agrochemicals and drugs. 
In this study, we described the isolation and structure identification of six new prenylated indole diketopiperazine alkaloids (1-6), together with eight known analogues: Gartryprostatin A (7) [15], gartryprostatin B (8) [15], sclerotiamide (9) [16], notoamide H (10) [17], 6-epi-notoamide R (11) [18], notoamide R (12) [19], (-)-notoamide I (13) [20], and gartryprostatin C (14) [15] (Figure 1) from the marine-derived endophytic fungus Aspergillus sp. YJ191021. All compounds were assayed for their inhibition against three agricultural pathogenic fungi, Rhizoctonia solani, Fusarium oxysporum, Colletotrichum gloeosporioides penz, and two agricultural pathogenic bacteria Xanthomonas oryzae pv. Oryzae, and X. oryzae pv. oryzicola. Furthermore, part of the compounds was evaluated for their anti-inflammatory activity in Propionibacterium acnes-stimulated THP-1 human monocytic cell line. Herein, we described the isolation, structural identification, and biological evaluation of the isolated diketopiperazine alkaloids.
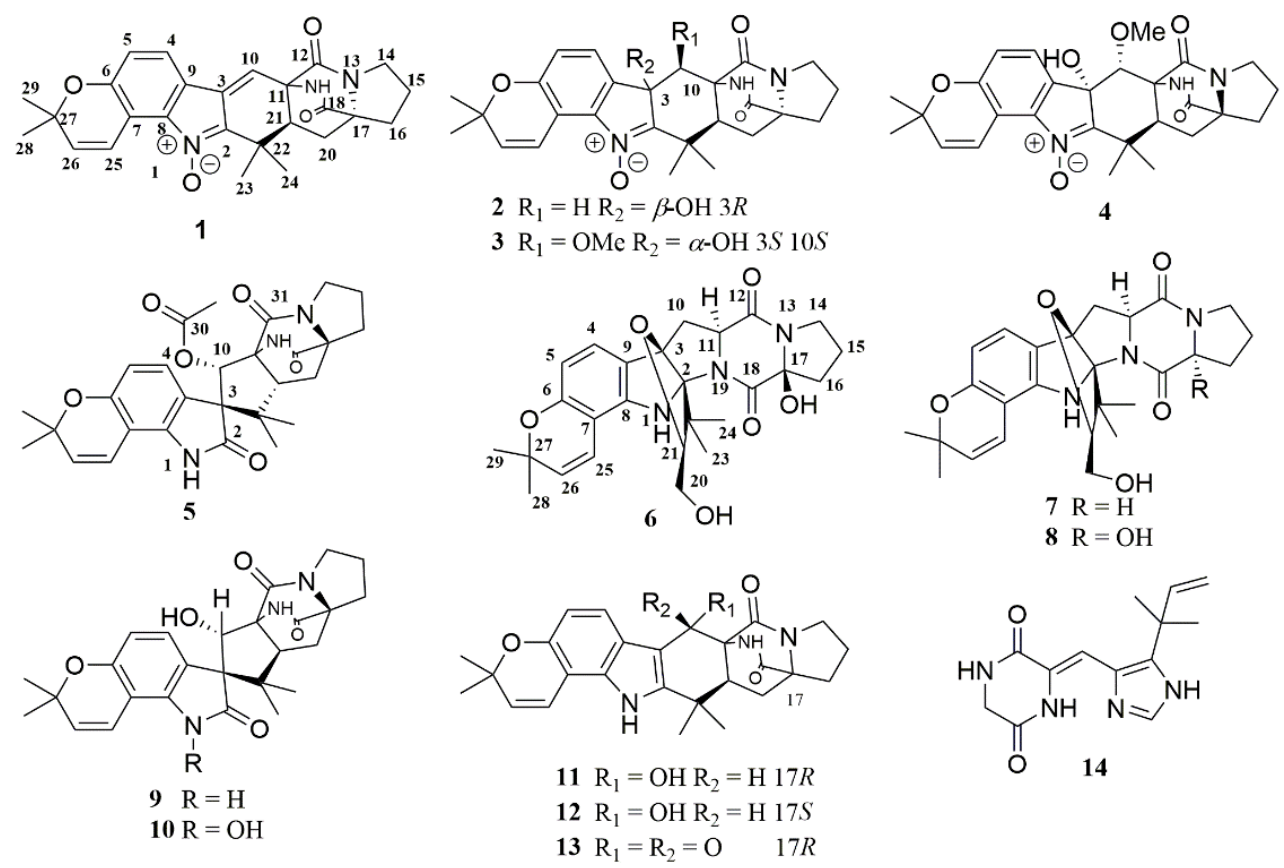

Figure 1. Structures of 1-14.

\section{Results and Discussion}

Asperthrin A (1) was isolated as brilliant yellowish powders. Based on the $[\mathrm{M}+\mathrm{H}]^{+}$ ion peak at $m / z 446.2071$ (calcd. for $\mathrm{C}_{26} \mathrm{H}_{28} \mathrm{~N}_{3} \mathrm{O}_{4}, 446.2074$ ) in the HR-ESI-MS data and ${ }^{13} \mathrm{C}$ NMR data, its molecular formula was determined as $\mathrm{C}_{26} \mathrm{H}_{27} \mathrm{~N}_{3} \mathrm{O}_{4}$, indicating 15 degrees of unsaturation. For the NMR data (Table 1), the characteristic signals were attributed based on careful analyses of ${ }^{1} \mathrm{H}$ NMR, ${ }^{13} \mathrm{C}$ NMR, and HSQC spectra (Figures S1-S4) as follows: Four methyl groups at $\delta_{\mathrm{H}} 1.22(3 \mathrm{H}, \mathrm{s}, \mathrm{Me}-23), 1.55(3 \mathrm{H}, \mathrm{s}, \mathrm{Me}-24), 1.42(3 \mathrm{H}, \mathrm{s}, \mathrm{Me}-28)$, $1.41(3 \mathrm{H}, \mathrm{s}, \mathrm{Me}-29)$, one methine proton signal at $\delta_{\mathrm{H}} 2.31(1 \mathrm{H}, \mathrm{dd}, J=10.2,5.6 \mathrm{~Hz}, \mathrm{H}-21)$, five olefinic protons at $\delta_{\mathrm{H}} 7.80(1 \mathrm{H}, \mathrm{d}, J=8.0 \mathrm{~Hz}, \mathrm{H}-4), 6.88(1 \mathrm{H}, \mathrm{d}, J=8.0 \mathrm{~Hz}, \mathrm{H}-5), 7.05(1 \mathrm{H}$, s, H-10), $7.74(1 \mathrm{H}, \mathrm{d}, J=10.2 \mathrm{~Hz}, \mathrm{H}-25), 5.96(1 \mathrm{H}, \mathrm{d}, J=10.2 \mathrm{~Hz}, \mathrm{H}-26)$, one exchangeable proton at $\delta_{\mathrm{H}} 8.82(1 \mathrm{H}, \mathrm{s}, \mathrm{NH}-19)$, as well as eight aliphatic protons at $\delta_{\mathrm{H}} 1.83-3.40(8 \mathrm{H}$, $\left.\mathrm{m}, \mathrm{H}_{2}-14, \mathrm{H}_{2}-15, \mathrm{H}_{2}-16, \mathrm{H}_{2}-20\right)$ attributable to four methylene groups. The ${ }^{13} \mathrm{C} N M R$ and DEPT data disclosed 26 carbon signals, including four $s p^{3}$ non-protonated carbons at $\delta_{\mathrm{C}}$ 60.3 (C-11), 66.5 (C-17), 35.6 (C-22) [one oxygen-bearing $s p^{3}$ carbon at $\delta_{\mathrm{C}} 77.1$ (C-27)], and eight $s p^{2}$ non-protonated carbons $\left(\delta_{C} 145.4,132.7,155.1,111.4,139.6,117.6,168.2\right.$, and 172.1). There were odd numbers of olefinic carbon signals in the ${ }^{13} \mathrm{C}$ NMR spectrum, which implied that the double bond in the indole ring was connected between the carbon atom and nitrogen atom. According to the previously introduced molecular formula, there were four oxygen atoms in compound 1. Except for two carbonyl groups and one cyclic ether 
group, the last oxygen atom was deducted to form the imine-oxide group located at 1-N. The presence of six double bonds and two carbonyls accounted for eight of the 15 degrees of unsaturation, indicating the existence of a heptatomic ring system for $\mathbf{1}$.

Table 1. ${ }^{1} \mathrm{H}(600 \mathrm{MHz})$ NMR Data of $\mathbf{1 - 6 .}$

\begin{tabular}{|c|c|c|c|c|c|c|}
\hline \multirow{2}{*}{ Position } & $1^{a}$ & $2^{a}$ & $3^{a}$ & $4^{a}$ & $5^{a}$ & $6^{b}$ \\
\hline & $\delta_{\mathrm{H}}(J$ in $\mathrm{Hz})$ & $\delta_{\mathrm{H}}(J$ in $\mathrm{Hz})$ & $\delta_{\mathrm{H}}(J$ in $\mathrm{Hz})$ & $\delta_{\mathrm{H}}(J$ in $\mathrm{Hz})$ & $\delta_{\mathrm{H}}(J$ in $\mathrm{Hz})$ & $\delta_{\mathrm{H}}(J$ in $\mathrm{Hz})$ \\
\hline $1(\mathrm{NH})$ & & & & & $10.69(\mathrm{~s})$ & \\
\hline 4 & $7.80(\mathrm{~d}, 8.0)$ & $7.32(\mathrm{~d}, 8.0)$ & $7.43(\mathrm{~d}, 8.0)$ & $7.36(\mathrm{~d}, 8.1)$ & $6.89(\mathrm{~d}, 8.1)$ & $6.97(\mathrm{~d}, 8.1)$ \\
\hline 5 & $6.88(\mathrm{~d}, 8.0)$ & $6.85(\mathrm{~d}, 8.0)$ & $6.83(\mathrm{~d}, 8.0)$ & $6.88(\mathrm{~d}, 8.1)$ & $6.36(\mathrm{~d}, 8.1)$ & $6.20(\mathrm{~d}, 8.1)$ \\
\hline 10 & $7.05(\mathrm{~s})$ & $\begin{array}{l}\text { a } 2.64(\mathrm{~d}, 15.2) \\
\text { b } 2.05(\mathrm{~d}, 15.2)\end{array}$ & $4.72(\mathrm{~s})$ & $4.12(\mathrm{~d}, 1.2)$ & $5.75(\mathrm{~s})$ & $\begin{array}{c}\text { a } 2.72(\mathrm{dd}, 12.9,7.0) \\
\text { b } 2.59(\mathrm{~m})\end{array}$ \\
\hline 11 & & & & & & $4.59(\mathrm{dd}, 11.9,7.0)$ \\
\hline 14 & $\begin{array}{l}\text { a } 3.40(\mathrm{~m}) \\
\text { b } 3.34(\mathrm{~m})\end{array}$ & $\begin{array}{l}\text { a } 3.34(\mathrm{~m}) \\
\text { b } 3.29(\mathrm{~m})\end{array}$ & $3.36(\mathrm{~m})$ & $3.40(t, 6.5)$ & $\begin{array}{l}\text { a } 3.40(\mathrm{~m}) \\
\text { b } 3.30(\mathrm{~m})\end{array}$ & $3.56(\mathrm{~m})$ \\
\hline 15 & a $2.00(\mathrm{~m})$ & a $1.97(\mathrm{~m})$ & a $1.99(\mathrm{~m})$ & a $2.02(\mathrm{~m})$ & a $1.99(\mathrm{~m})$ & a $1.99(\mathrm{~m})$ \\
\hline & b $1.84(\mathrm{~m})$ & b $1.81(\mathrm{~m})$ & b $1.81(\mathrm{~m})$ & b $1.85(\mathrm{~m})$ & b $1.86(\mathrm{~m})$ & b $1.90(\mathrm{~m})$ \\
\hline 16 & a $2.53(\mathrm{~m})$ & a $2.50(\mathrm{~m})$ & a $2.54(\mathrm{~m})$ & a $2.54(\mathrm{~m})$ & a $2.48(\mathrm{~m})$ & a $2.33(\mathrm{~m})$ \\
\hline & b $1.83(\mathrm{~m})$ & b $1.83(\mathrm{~m})$ & b $1.81(\mathrm{~m})$ & b $1.85(\mathrm{~m})$ & b $1.80(\mathrm{~m})$ & b $2.10(\mathrm{~m})$ \\
\hline 19(NH) & $8.82(\mathrm{~s})$ & $7.52(\mathrm{~s})$ & $7.74(\mathrm{~s})$ & $7.87(\mathrm{~s})$ & $8.54(\mathrm{~s})$ & \\
\hline 20 & $\begin{array}{c}\text { a } 2.21(\mathrm{dd}, 13.4, \\
10.2)\end{array}$ & a $2.13(\mathrm{~m})$ & $\begin{array}{c}\text { a } 2.10(\mathrm{dd}, 13.2, \\
10.3)\end{array}$ & a $2.02(\mathrm{~m})$ & a $2.04(\mathrm{~m})$ & a $3.64(\mathrm{~m})$ \\
\hline & b $1.89(\mathrm{~m})$ & b $1.85(\mathrm{~m})$ & b $1.75(\mathrm{~m})$ & b $1.85(\mathrm{~m})$ & b $1.79(\mathrm{~m})$ & b $3.56(\mathrm{~m})$ \\
\hline 21 & $2.31(\mathrm{dd}, 10.2,5.6)$ & $2.13(\mathrm{~m})$ & $3.08(\mathrm{dd}, 10.3,6.5)$ & $3.53(\mathrm{dd}, 10.1,7.8)$ & $2.68(\mathrm{dd}, 10.2,6.5)$ & $3.81(\mathrm{dd}, 7.6,2.8)$ \\
\hline 23 & $1.22(\mathrm{~s})$ & $1.34(\mathrm{~s})$ & $1.31(\mathrm{~s})$ & $1.15(\mathrm{~s})$ & $0.52(\mathrm{~s})$ & $1.29(\mathrm{~s})$ \\
\hline 24 & $1.55(\mathrm{~s})$ & $1.54(\mathrm{~s})$ & $1.32(\mathrm{~s})$ & $1.30(\mathrm{~s})$ & $1.12(\mathrm{~s})$ & $0.82(\mathrm{~s})$ \\
\hline 25 & $7.74(\mathrm{~d}, 10.2)$ & $7.83(\mathrm{~d}, 10.2)$ & $7.78(\mathrm{~d}, 10.2)$ & $7.76(\mathrm{~d}, 10.1)$ & $6.57(\mathrm{~d}, 9.8)$ & $6.15(\mathrm{~d}, 9.9)$ \\
\hline 26 & $5.96(\mathrm{~d}, 10.2)$ & $5.90(\mathrm{~d}, 10.2)$ & $5.92(\mathrm{~d}, 10.2)$ & $5.93(\mathrm{~d}, 10.1)$ & $5.75(\mathrm{~d}, 9.8)$ & $5.50(\mathrm{~d}, 9.9)$ \\
\hline 28 & $1.42(\mathrm{~s})$ & $1.39(\mathrm{~s})$ & $1.41(\mathrm{~s})$ & $1.42(\mathrm{~s})$ & $1.38(\mathrm{~s})$ & $1.37(\mathrm{~s})$ \\
\hline 29 & $1.41(\mathrm{~s})$ & $1.39(\mathrm{~s})$ & $1.39(\mathrm{~s})$ & $1.40(\mathrm{~s})$ & $1.35(\mathrm{~s})$ & $1.35(\mathrm{~s})$ \\
\hline 31 & & & & & $2.03(\mathrm{~s})$ & \\
\hline $3-\mathrm{OH}$ & & $6.39(\mathrm{~s})$ & $6.31(\mathrm{~s})$ & $6.27(\mathrm{~d}, 1.2)$ & & \\
\hline OMe-10 & & & $3.03(\mathrm{~s})$ & $3.31(\mathrm{~s})$ & & \\
\hline
\end{tabular}

${ }^{\text {a }}$ Measured at $600 \mathrm{MHz}\left({ }^{1} \mathrm{H}\right)$ in $\mathrm{CDCl}_{3} ;{ }^{\mathrm{b}}$ measured at $600 \mathrm{MHz}\left({ }^{1} \mathrm{H}\right)$ in DMSO- $d_{6}$.

The connection fragment of $\mathbf{1}$ was further confirmed by analysis of the HMBC spectrum (Figure S5). The HMBC correlations from H-4 $\left(\delta_{\mathrm{H}} 7.80\right)$ to $\mathrm{C}-3\left(\delta_{\mathrm{C}} 132.7\right) / \mathrm{C}-6\left(\delta_{\mathrm{C}}\right.$ $155.1) / \mathrm{C}-8\left(\delta_{\mathrm{C}} 139.6\right)$, and H-26 $\left(\delta_{\mathrm{H}} 5.96\right)$ to $\mathrm{C}-7\left(\delta_{\mathrm{C}} 111.4\right) / \mathrm{C}-27\left(\delta_{\mathrm{C}} 77.1\right) / \mathrm{C}-28\left(\delta_{\mathrm{C}} 27.9\right)$ indicated the presence of the isopentenyl-substituted indole motif (Figure 2). The bicyclo [2.2.2] diazaoctane ring, biosynthetically derived from a diketopiperazine ring and an isoprenyl group, was indicated by key HMBC correlations from $\mathrm{H}-20 \mathrm{a}\left(\delta_{\mathrm{H}} 2.21\right)$ to $\mathrm{C}-11$ $\left(\delta_{\mathrm{C}} 60.3\right) / \mathrm{C}-17\left(\delta_{\mathrm{C}} 66.5\right) / \mathrm{C}-18\left(\delta_{\mathrm{C}} 172.1\right) / \mathrm{C}-21\left(\delta_{\mathrm{C}} 46.3\right)$ and from H-21 $\left(\delta_{\mathrm{H}} 2.31\right)$ to C-12 $\left(\delta_{\mathrm{C}} 168.2\right) / \mathrm{C}-22\left(\delta_{\mathrm{C}} 35.6\right) / \mathrm{C}-23\left(\delta_{\mathrm{C}} 17.5\right)$. Besides, the HMBC correlations from H-10 $\left(\delta_{\mathrm{H}}\right.$ $7.05)$ to $\mathrm{C}-2\left(\delta_{\mathrm{C}} 145.4\right) / \mathrm{C}-21\left(\delta_{\mathrm{C}} 46.3\right)$ and from H-23 $\left(\delta_{\mathrm{H}} 1.22\right)$ to C-2 $\left(\delta_{\mathrm{C}} 145.4\right) / \mathrm{C}-21\left(\delta_{\mathrm{C}}\right.$ 46.3) proved the existence of a conjugated exo-double bond-bearing cyclohexene, which was formed by the connection between prenylated indole and diazaoctane moieties. Based on the spectral analysis, the planar structure of $\mathbf{1}$ was the same as 6-epi-avrainvillamide, isolated from $A$. taichungensis [18].

The ROESY spectrum (Figure 3 and Figure S6) exhibited correlations between 19-NH $\left(\delta_{\mathrm{H}} 8.82\right)$ and $\mathrm{H}-23\left(\delta_{\mathrm{H}} 1.22\right)$, between $\mathrm{H}-21\left(\delta_{\mathrm{H}} 2.31\right)$ and $\mathrm{H}-24\left(\delta_{\mathrm{H}} 1.55\right)$, supporting that $\mathrm{H}-21$ and $\mathrm{H}-24$ were co-facial and assigned as $\alpha$-oriented whereas $\mathrm{H}-23$ is $\beta$-oriented, respectively. Additionally, the absence of a cross peak between H-21 $\left(\delta_{\mathrm{H}} 2.31\right)$ and 19$\mathrm{NH}\left(\delta_{\mathrm{H}} 8.82\right)$ indicated that the relative configuration between N13-C17 and C21-22 was anti [21]. Williams reported that the Cotton effect at $\lambda=200-250 \mathrm{~nm}$ arising from an $\mathrm{n}-\pi^{*}$ transition of the diketopiperazine moiety is diagnostic of the bicyclo[2.2.2]diazaoctane ring system [21,22]. The negative Cotton effect at $225 \mathrm{~nm}$ in ECD spectrum (Figure $4 \mathrm{~A}$ and Figure S8), which was opposite to that of 6-epi-avrainvillamide [18], empirically indicated that the absolute configurations of $\mathrm{C}-11$ and $\mathrm{C}-17$ in 1 were $11 R$, and $17 R$. Combined with the analysis of the ROESY spectrum, the absolute configuration of C-21 was assigned as $21 S$. 
To further verify the aforementioned absolute configuration deduction of $\mathbf{1}$, the calculated ECD spectrum was conducted. The absolute configurations of $11 R, 17 R$, and $21 S$ were determined for the well match between the calculated and the experimental ECD spectra (Figure 4A).
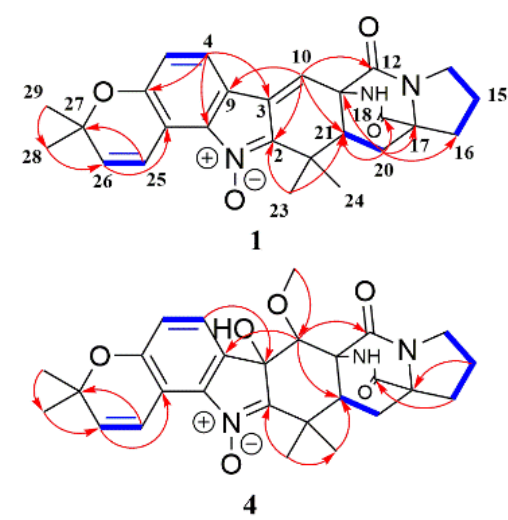
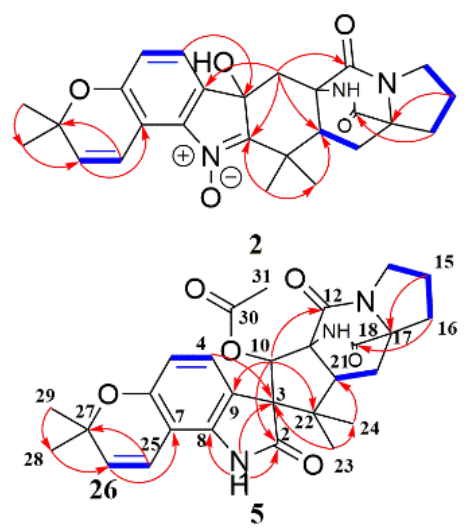
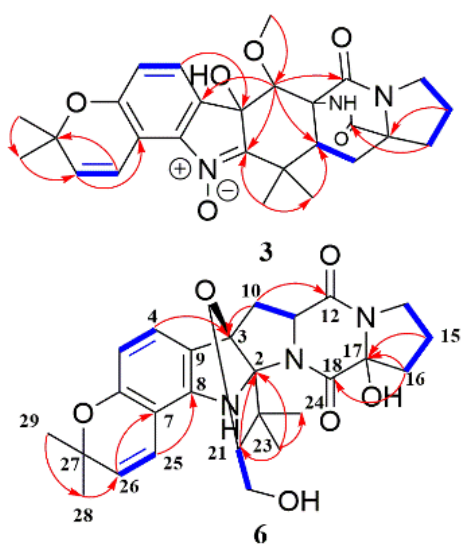

Figure 2. ${ }^{1} \mathrm{H}-{ }^{1} \mathrm{H}$ COSY (bold blue lines) and key HMBC (red arrows) correlations for 1-6.
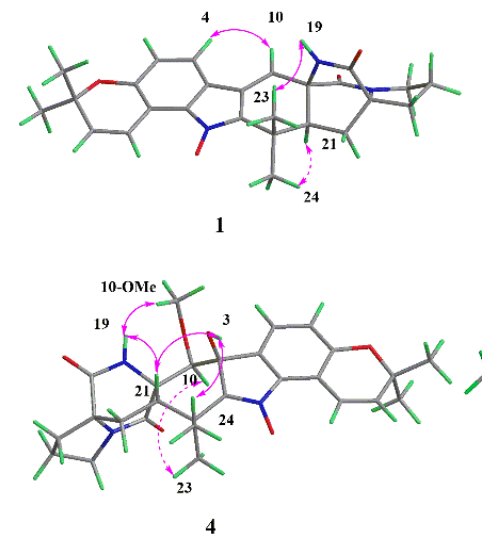


5 ROESY II fope back face


Figure 3. Key ROESY correlations for 1-6.

Asperthrin B (2) was obtained as white powders. The molecular formula $\mathrm{C}_{26} \mathrm{H}_{29} \mathrm{~N}_{3} \mathrm{O}_{5}$, which was determined by the $[\mathrm{M}+\mathrm{Na}]^{+}$ion at $m / z 486.2002$ (calcd. for $\mathrm{C}_{26} \mathrm{H}_{29} \mathrm{~N}_{3} \mathrm{O}_{5} \mathrm{Na}$, 486.1999) from the HR-ESI-MS and ${ }^{13} \mathrm{C}$ NMR data was 18 amu higher than the molecular mass of $\mathbf{1}$, implying the presence of an additional hydroxy group in its structure. A careful comparison of the ${ }^{13} \mathrm{C}$ NMR data of $\mathbf{2}$ with those of $\mathbf{1}$ (Table 2) showed significant upfield shifts of $\mathrm{C}-3\left(\delta_{\mathrm{C}} 75.8\right)$ and $\mathrm{C}-10\left(\delta_{\mathrm{C}} 36.0\right)$, indicating a saturation of the double bond between $\mathrm{C}-3$ and $\mathrm{C}-10$. The HMBC correlations from $\mathrm{H}-4\left(\delta_{\mathrm{H}} 7.32\right)$ to $\mathrm{C}-3\left(\delta_{\mathrm{C}} 75.8\right)$ (Figure 2 and Figure S14) confirmed that the hydroxyl group was attached to C-3. The ROESY correlations (Figure 3 and Figure S15) from 19-NH $\left(\delta_{\mathrm{H}} 7.52\right)$ to $\mathrm{H}-23\left(\delta_{\mathrm{H}} 1.34\right)$ and $\mathrm{H}-10 \mathrm{a}\left(\delta_{\mathrm{H}} 2.64\right)$ to $3-\mathrm{OH}\left(\delta_{\mathrm{H}} 6.39\right) / 19-\mathrm{NH}\left(\delta_{\mathrm{H}} 7.52\right) / \mathrm{H}-23\left(\delta_{\mathrm{H}} 1.34\right)$ indicated these protons were co-facial and $\beta$-oriented. Accordingly, the ROESY correlations between H-21 $\left(\delta_{\mathrm{H}} 2.13\right)$ and $\mathrm{H}-24\left(\delta_{\mathrm{H}}\right.$ 1.54) revealed that $\mathrm{H}-21$ and $\mathrm{H}-24$ were $\alpha$-oriented. The absolute configurations of $\mathrm{C}-3$, $\mathrm{C}-11, \mathrm{C}-17$, and C-21 in 2 were assigned as $3 R, 11 R, 17 R$, and $21 S$ based on the negative Cotton effect at $225 \mathrm{~nm}$ in ECD spectra (Figure $4 \mathrm{~B}$ and Figure S17) and calculated ECD spectra (Figure 4B). 


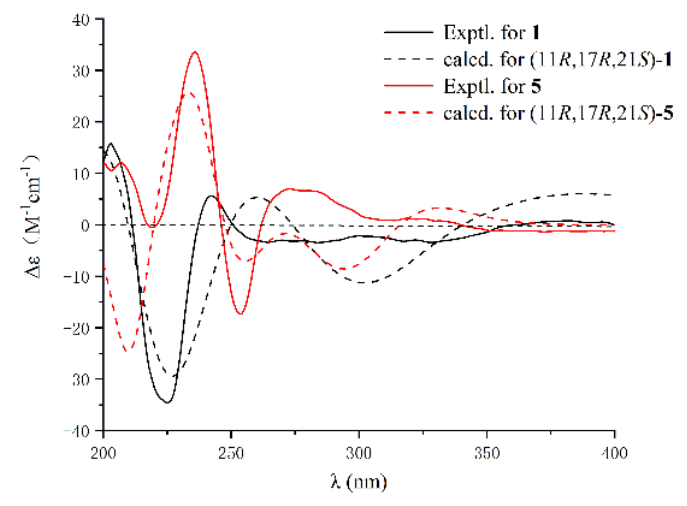

A

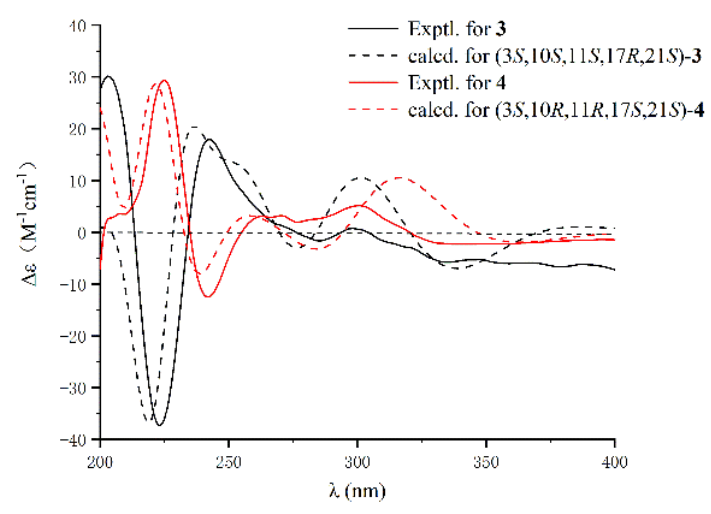

C

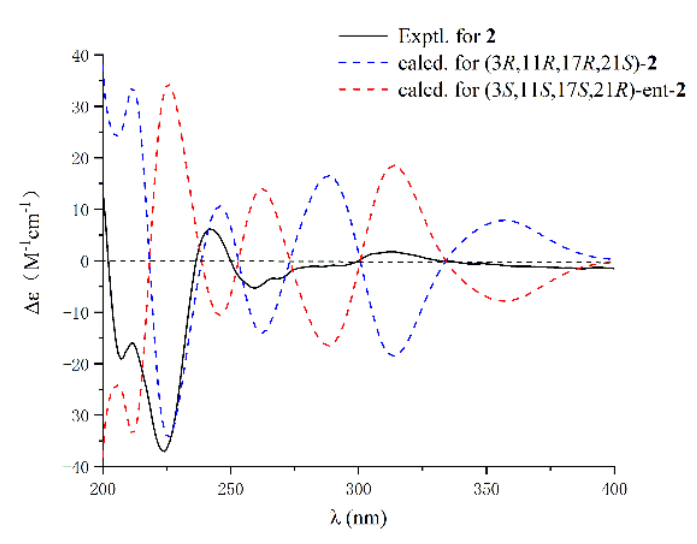

B

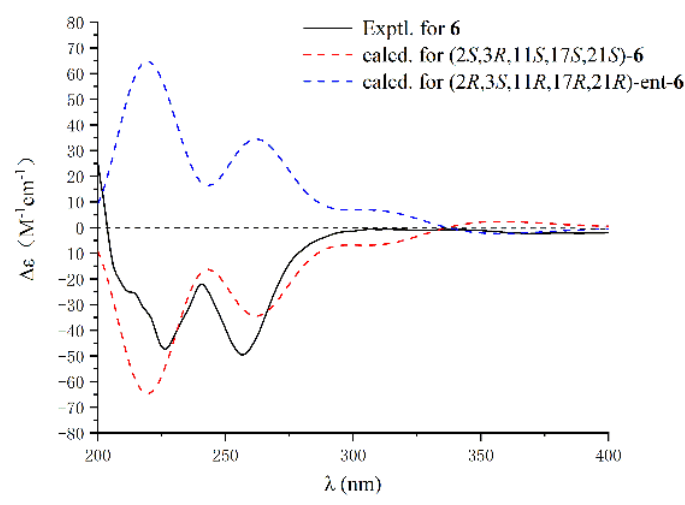

D

Figure 4. Experimental and calculated ECD spectra for 1-6. (A) for 1 and 5; (B) for 2; (C) for 3 and 4; (D) for 6.

Asperthrin C (3) was isolated as white powders. Based on the $[\mathrm{M}+\mathrm{Na}]^{+}$ion at $\mathrm{m} / \mathrm{z}$ 516.2102 (calcd. for $\mathrm{C}_{27} \mathrm{H}_{31} \mathrm{~N}_{3} \mathrm{O}_{6} \mathrm{Na}, 516.2105$ ) in the (+)- HR-ESI-MS and ${ }^{13} \mathrm{C}$ NMR data, the molecular formula was determined as $\mathrm{C}_{27} \mathrm{H}_{31} \mathrm{~N}_{3} \mathrm{O}_{6}$, which was 30 amu more than 2 . Comparation of the ${ }^{1} \mathrm{H}$ NMR spectrum (Figure S19) of $\mathbf{3}$ with that of $\mathbf{2}$ indicated that there was a methoxy group in 3 . The HMBC correlation from OMe-10 $\left(\delta_{\mathrm{H}} 3.03\right)$ to $\mathrm{C}-10\left(\delta_{\mathrm{C}} 76.9\right)$ (Figure 2 and Figure S23) suggested that the methoxy group was attached to $\mathrm{C}-10$. The ROESY correlations (Figure 3 and Figure S24) between 19-NH $\left(\delta_{\mathrm{H}} 7.74\right)$ and OMe- $10\left(\delta_{\mathrm{H}}\right.$ $3.03) / \mathrm{H}-23\left(\delta_{\mathrm{H}} 1.31\right)$ indicated that these protons were co-facial and assigned as $\beta$-oriented. The ROESY correlations between $3-\mathrm{OH}\left(\delta_{\mathrm{H}} 6.31\right)$ and $\mathrm{H}-10\left(\delta_{\mathrm{H}} 4.72\right) / \mathrm{H}-21\left(\delta_{\mathrm{H}} 3.08\right)$, and between $\mathrm{H}-21\left(\delta_{\mathrm{H}} 3.08\right)$ to $\mathrm{H}-24\left(\delta_{\mathrm{H}} 1.32\right)$, indicated that they were in the $\alpha$-orientation. Based on the negative Cotton effect at $225 \mathrm{~nm}$ in ECD spectra (Figure 4C and Figure S26) and the well match result between experimental and calculated ECD spectra (Figure 4C), the absolute configurations of C-3, C-10, C-11, C-17, and C-21 in 3 were assigned as 3S, 10S, $11 S, 17 R$, and 21S.

Asperthrin $\mathrm{D}(4)$ was isolated as white powders. The molecular formula was determined as $\mathrm{C}_{27} \mathrm{H}_{31} \mathrm{~N}_{3} \mathrm{O}_{6}$ by the (+)-HRESIMS data from the $[\mathrm{M}+\mathrm{Na}]^{+}$ion at $m / z 516.2106$ (calcd. for $\mathrm{C}_{27} \mathrm{H}_{31} \mathrm{~N}_{3} \mathrm{O}_{6} \mathrm{Na}, 516.2105$ ) as same as that of 3. Detailed analyses of the 1D NMR and 2D NMR spectra (Figures S28-S32) indicated that the planar structure of 4 was the same as that of 3 . However, the chemical shifts of $\mathrm{H}-10\left(\delta_{\mathrm{H}} 4.12\right)$ and OMe-10 $\left(\delta_{\mathrm{H}} 3.31\right)$ in 4 differed from those of 3 , implying that the configuration of C-10 was opposite to that of 3 . The relative configuration was assigned by the ROESY correlations from $19-\mathrm{NH}\left(\delta_{\mathrm{H}} 7.87\right)$ to OMe-10 $\left(\delta_{\mathrm{H}} 3.31\right) / \mathrm{H}-21\left(\delta_{\mathrm{H}} 3.53\right), 3-\mathrm{OH}\left(\delta_{\mathrm{H}} 6.27\right)$ to $\mathrm{H}-21\left(\delta_{\mathrm{H}} 3.53\right) / \mathrm{H}-24\left(\delta_{\mathrm{H}} 1.30\right)$, and $\mathrm{H}-10$ $\left(\delta_{\mathrm{H}} 4.12\right)$ to $\mathrm{H}-23\left(\delta_{\mathrm{H}} 1.15\right)$ (Figure 3 and Figure S33). The absolute configurations of C-3, C-10, C-11 C-17, and C-21 in 4 were assigned as 3S, 10R, 11R, 17S, $21 S$ based on the positive Cotton effect at $225 \mathrm{~nm}$ and the calculated ECD spectra results (Figure 4C and Figure S35). 
Table 2. ${ }^{13} \mathrm{C}(150 \mathrm{MHz})$ NMR Data of 1-6.

\begin{tabular}{|c|c|c|c|c|c|c|}
\hline \multirow{2}{*}{ Position } & $1^{a}$ & $2^{a}$ & $3^{a}$ & $4^{a}$ & $5^{a}$ & $6^{b}$ \\
\hline & $\delta \mathrm{c}$, Type & $\delta \mathrm{c}$, Type & $\delta \mathrm{c}$, Type & $\delta \mathrm{c}$, Type & $\delta \mathrm{c}$, Type & $\delta \mathrm{c}$, Type \\
\hline 2 & $145.4, \mathrm{C}$ & $151.2, \mathrm{C}$ & 153.3, C & $152.4, \mathrm{C}$ & $176.3, \mathrm{C}$ & $98.6, \mathrm{C}$ \\
\hline 3 & 132.7, C & $75.8, C$ & $78.5, \mathrm{C}$ & $78.0, \mathrm{C}$ & $64.3, \mathrm{C}$ & $97.1, \mathrm{C}$ \\
\hline 4 & $121.7, \mathrm{CH}$ & $121.9, \mathrm{CH}$ & $123.1, \mathrm{CH}$ & $124.2, \mathrm{CH}$ & $125.0, \mathrm{CH}$ & $125.2, \mathrm{CH}$ \\
\hline 5 & $116.3, \mathrm{CH}$ & $116.7, \mathrm{CH}$ & 116.1, CH & $116.9, \mathrm{CH}$ & $108.7, \mathrm{CH}$ & $108.0, \mathrm{CH}$ \\
\hline 6 & 155.1, C & 154.3, C & $154.2, \mathrm{C}$ & 154.4, C & $152.5, \mathrm{C}$ & 155.1, C \\
\hline 7 & $111.4, \mathrm{C}$ & $112.3, \mathrm{C}$ & 112.0, C & $111.9, \mathrm{C}$ & $104.8, \mathrm{C}$ & 103.7, C \\
\hline 8 & $139.6, \mathrm{C}$ & $140.0, \mathrm{C}$ & $140.9, \mathrm{C}$ & $140.1, \mathrm{C}$ & $138.0, \mathrm{C}$ & $146.8, \mathrm{C}$ \\
\hline 9 & $117.6, \mathrm{C}$ & $131.2, \mathrm{C}$ & 129.3, C & $129.4, \mathrm{C}$ & $124.6, \mathrm{C}$ & $118.8, \mathrm{C}$ \\
\hline 10 & $121.8, \mathrm{CH}$ & 36.0, $\mathrm{CH}_{2}$ & $76.9, \mathrm{CH}$ & $76.1, \mathrm{CH}$ & $74.1, \mathrm{CH}$ & $38.9, \mathrm{CH}_{2}$ \\
\hline 11 & $60.3, \mathrm{C}$ & $61.7, C^{2}$ & $62.1, \mathrm{C}$ & $62.3, \mathrm{C}$ & $68.9, \mathrm{C}$ & $63.4, \mathrm{CH}$ \\
\hline 12 & $168.2, \mathrm{C}$ & $168.4, \mathrm{C}$ & $168.7, \mathrm{C}$ & $168.5, \mathrm{C}$ & $168.1, \mathrm{C}$ & 167.1, C \\
\hline 14 & $44.2, \mathrm{CH}_{2}$ & 44.0, $\mathrm{CH}_{2}$ & $44.3, \mathrm{CH}_{2}$ & $44.4, \mathrm{CH}_{2}$ & $43.9, \mathrm{CH}_{2}$ & $45.3, \mathrm{CH}_{2}$ \\
\hline 15 & $24.4, \mathrm{CH}_{2}$ & $24.3, \mathrm{CH}_{2}$ & $24.6, \mathrm{CH}_{2}$ & $24.5, \mathrm{CH}_{2}$ & $24.9, \mathrm{CH}_{2}$ & 21.0, $\mathrm{CH}_{2}$ \\
\hline 16 & $29.0, \mathrm{CH}_{2}$ & $28.9, \mathrm{CH}_{2}$ & $29.0, \mathrm{CH}_{2}$ & $29.1, \mathrm{CH}_{2}$ & $28.1, \mathrm{CH}_{2}$ & $31.6, \mathrm{CH}_{2}$ \\
\hline 17 & $66.5, \mathrm{C}$ & $66.8, C$ & $66.9, \mathrm{C}$ & $66.8, \mathrm{C}$ & $69.3, \mathrm{C}$ & $93.6, \mathrm{C}$ \\
\hline 18 & $172.1, \mathrm{C}$ & $172.4, \mathrm{C}$ & $172.4, \mathrm{C}$ & $172.2, \mathrm{C}$ & $172.5, \mathrm{C}$ & $165.4, \mathrm{C}$ \\
\hline 20 & $30.5, \mathrm{CH}_{2}$ & $31.8, \mathrm{CH}_{2}$ & $29.2, \mathrm{CH}_{2}$ & $30.5, \mathrm{CH}_{2}$ & $27.9, \mathrm{CH}_{2}$ & $61.8, \mathrm{CH}_{2}$ \\
\hline 21 & $46.3, \mathrm{CH}$ & $48.7, \mathrm{CH}$ & $42.0, \mathrm{CH}$ & $50.0, \mathrm{CH}$ & $51.1, \mathrm{CH}$ & $91.1, \mathrm{CH}$ \\
\hline 22 & $35.6, \mathrm{C}$ & $38.6, \mathrm{C}$ & $36.8, \mathrm{C}$ & $36.6, \mathrm{C}$ & $47.2, \mathrm{C}$ & 46.7, C \\
\hline 23 & $17.5, \mathrm{CH}_{3}$ & 21.2, $\mathrm{CH}_{3}$ & $14.3, \mathrm{CH}_{3}$ & $13.5, \mathrm{CH}_{3}$ & $25.6, \mathrm{CH}_{3}$ & 21.2, $\mathrm{CH}_{3}$ \\
\hline 24 & $23.4, \mathrm{CH}_{3}$ & $27.0, \mathrm{CH}_{3}$ & $22.9, \mathrm{CH}_{3}$ & $22.8, \mathrm{CH}_{3}$ & $21.3, \mathrm{CH}_{3}$ & $18.2, \mathrm{CH}_{3}$ \\
\hline 25 & $115.8, \mathrm{CH}$ & $116.3, \mathrm{CH}$ & 116.0, $\mathrm{CH}$ & $115.9, \mathrm{CH}$ & $117.2, \mathrm{CH}$ & $116.6, \mathrm{CH}$ \\
\hline 26 & 133.7, CH & $133.2, \mathrm{CH}$ & $133.3, \mathrm{CH}$ & $133.5, \mathrm{CH}$ & $130.8, \mathrm{CH}$ & $129.1, \mathrm{CH}$ \\
\hline 27 & 77.1, C & $76.5, \mathrm{C}$ & $76.6, \mathrm{C}$ & 76.7, C & $76.3, \mathrm{C}$ & 76.0, C \\
\hline 28 & $27.9, \mathrm{CH}_{3}$ & $27.8, \mathrm{CH}_{3}$ & $27.9, \mathrm{CH}_{3}$ & $27.9, \mathrm{CH}_{3}$ & $28.8, \mathrm{CH}_{3}$ & $28.2, \mathrm{CH}_{3}$ \\
\hline 29 & $27.9, \mathrm{CH}_{3}$ & $27.8, \mathrm{CH}_{3}$ & $27.8, \mathrm{CH}_{3}$ & $27.9, \mathrm{CH}_{3}$ & $27.9, \mathrm{CH}_{3}$ & 27.6, $\mathrm{CH}_{3}$ \\
\hline 30 & & & & & $170.0, \mathrm{C}$ & \\
\hline 31 & & & & & 21.0, $\mathrm{CH}_{3}$ & \\
\hline 10-OMe & & & $61.8, \mathrm{CH}_{3}$ & $60.0, \mathrm{CH}_{3}$ & & \\
\hline
\end{tabular}

a Measured at $150 \mathrm{MHz}\left({ }^{13} \mathrm{C}\right)$ in $\mathrm{CDCl}_{3} ;{ }^{\mathrm{b}}$ measured at $150 \mathrm{MHz}\left({ }^{13} \mathrm{C}\right)$ in DMSO- $d_{6}$.

Asperthrin $\mathrm{E}$ (5) was obtained as white powders. The molecular formula was determined as $\mathrm{C}_{28} \mathrm{H}_{31} \mathrm{~N}_{3} \mathrm{O}_{6}$ by the $[\mathrm{M}+\mathrm{H}]^{+}$ion at $m / z 528.2102$ (calcd. for $\mathrm{C}_{28} \mathrm{H}_{31} \mathrm{~N}_{3} \mathrm{O}_{6} \mathrm{Na}$, 528.2105) from HR-ESI-MS and ${ }^{13} \mathrm{C}$ NMR data. The proton signal at $\delta_{\mathrm{H}} 2.03(3 \mathrm{H}, \mathrm{s})$ in ${ }^{1} \mathrm{H}$ NMR spectrum (Figure S37) indicated the presence of an acetoxy group. The HMBC correlations from NH-1 $\left(\delta_{\mathrm{H}} 10.69\right)$ to $\mathrm{C}-2\left(\delta_{\mathrm{C}} 176.3\right)$ and $\mathrm{H}-4\left(\delta_{\mathrm{H}} 6.89\right) / \mathrm{H}-10\left(\delta_{\mathrm{H}} 5.75\right) / \mathrm{H}-23$ $\left(\delta_{\mathrm{H}} 0.52\right) / \mathrm{NH}-1\left(\delta_{\mathrm{H}} 10.69\right)$ to $\mathrm{C}-3\left(\delta_{\mathrm{C}} 64.3\right)$ (Figure 2 and Figure S41) indicated the presence of an indoxyl core with a spiro-quaternary center at C-3. Detailed analyses of $1 \mathrm{D}$ NMR and 2D NMR spectra (Figures S37-S41) indicated that the planar structure of $\mathbf{5}$ was the same as that of 10-O-acetylsclerotiamide [23]. The ROESY correlations (Figure 3 and Figure S42) from $19-\mathrm{NH}\left(\delta_{\mathrm{H}} 8.54\right)$ to $\mathrm{H}-24\left(\delta_{\mathrm{H}} 1.12\right)$ indicated that $\mathrm{NH}-19$ and $\mathrm{H}-24$ were located on the $\alpha$-face of the cyclopentane ring. The ROESY correlations from $\mathrm{H}-21\left(\delta_{\mathrm{H}} 2.68\right)$ to $\mathrm{H}-10$ $\left(\delta_{\mathrm{H}} 5.75\right) / \mathrm{H}-23\left(\delta_{\mathrm{H}} 0.52\right)$ indicated that these protons located on the $\beta$-orientation of the cyclopentane ring. Besides, the ROESY correlations from $\mathrm{H}-21\left(\delta_{\mathrm{H}} 2.68\right)$ to $\mathrm{H}-4\left(\delta_{\mathrm{H}} 6.89\right)$ indicated that the cyclopentane ring was orthogonal to the plane of the indoxyl ring. Based on the positive Cotton effect at $225 \mathrm{~nm}$ and the calculated ECD spectra results (Figure 4A and Figure S44), the absolute configurations of C-3, C-10, C-11, C-17, and C-21 in 5 were assigned as $3 R, 10 S, 11 R, 17 S, 21 R$.

Asperthrin $\mathrm{F}$ (6) was isolated as white powders, and the molecular formula was determined as $\mathrm{C}_{26} \mathrm{H}_{31} \mathrm{~N}_{3} \mathrm{O}_{6}$ by (+)-HRESIMS [M $\left.+\mathrm{Na}\right]^{+}$ion at $m / z 504.2103$ (calcd. for $\mathrm{C}_{26} \mathrm{H}_{31} \mathrm{~N}_{3} \mathrm{O}_{6} \mathrm{Na}$, 504.2105) and ${ }^{13} \mathrm{C}$ NMR data, indicating 13 degrees of unsaturation. The ${ }^{1} \mathrm{H}$ NMR, ${ }^{13} \mathrm{C}$ NMR, and HSQC spectra (Table 1, Table 2 and Figures S46-S49) showed four methyl groups, five $\mathrm{sp}^{3}$-methylenes (including one oxygen-bearing methylene), two $s p^{3}$-methine carbon signals (including one oxygenated carbon), five $s p^{3}$ non-protonated 
carbons (including three oxygen-bearing carbons), four olefinic methines, and six $s p^{2}$ nonprotonated carbons. The ${ }^{1} \mathrm{H}$ and ${ }^{13} \mathrm{C}$ NMR data of 6 resembled those of gartryprostatin $\mathrm{B}$ [15], with the exception that C-17 oxygen-bearing sp ${ }^{3}$-methine signal $\left(\delta_{\mathrm{C}} 93.6\right)$ and C-16 $s p^{3}$-methylene signal $\left(\delta_{\mathrm{H}} 2.10,2.33 ; \delta_{\mathrm{C}} 31.6\right)$ had a clear difference. With six degrees of unsaturation accounting for the eight aromatic carbons and two carbonyls, there must be a heptatomic ring system to meet the 13 degrees of unsaturation in $\mathbf{6}$. The HMBC correlations from H-21 $\left(\delta_{\mathrm{H}} 3.81\right)$ to $\mathrm{C}-2\left(\delta_{\mathrm{C}} 98.6\right), \mathrm{H}-23\left(\delta_{\mathrm{H}} 1.29\right)$ to $\mathrm{C}-2\left(\delta_{\mathrm{C}} 98.6\right) / \mathrm{C}-21\left(\delta_{\mathrm{C}} 91.1\right) / \mathrm{C}-24$ $\left(\delta_{\mathrm{C}} 18.2\right)$ (Figure 2 and Figure S50), and the deshielded shifts of C-3 $\left(\delta_{\mathrm{C}} 97.1\right) / \mathrm{C}-21\left(\delta_{\mathrm{C}}\right.$ 91.1) indicated that the furan ring was formed by an oxygen bridge between C-3 and C-21. Further detailed 1D and 2D NMR spectral analysis revealed that a planar structure of 6 was the same as that of gartryprostatin $\mathrm{B}$. The relative configuration of C-2/C-3/C-21 in the furan ring in 6 was determined by ROESY correlations from $\mathrm{H}-21\left(\delta_{\mathrm{H}} 3.81\right)$ to $\mathrm{H}-23$ $\left(\delta_{\mathrm{H}} 1.29\right), \mathrm{H}-10 \mathrm{~b}\left(\delta_{\mathrm{H}} 2.72\right)$ to $\mathrm{H}-4\left(\delta_{\mathrm{H}} 6.97\right)$, and $\mathrm{H}-24\left(\delta_{\mathrm{H}} 0.82\right)$ to $\mathrm{H}-10 \mathrm{a}\left(\delta_{\mathrm{H}} 2.59\right)$. Besides, the ROESY correlation from $\mathrm{H}-10 \mathrm{~b}\left(\delta_{\mathrm{H}} 2.72\right)$ to $\mathrm{H}-11\left(\delta_{\mathrm{H}} 4.59\right)$ determined the relative configurations of C-11. Based on the chemical shift differences of C-17 in ${ }^{13} \mathrm{C}$ NMR data, the relative configurations of $\mathrm{C}-17$ should be opposite to that of gartryprostatin $\mathrm{B}$. The absolute configurations of C-2, C-3, C-11, C-17, and C-21 in 6 were determined as 2S, $3 R, 11 S, 17 S, 21 S$ by the comparison between calculated and experimental ECD spectra (Figure 4D and Figure S53).

Compounds 1-14 were assayed for their anti-agricultural pathogenic and anti-inflammatory activities. As shown in Table 3, 1 displayed both antibacterial and antifungal activities with minimal inhibitory concentration (MIC) values of $50,12.5$, and $100 \mu \mathrm{g} / \mathrm{mL}$ against $X$. oryzae pv. oryzae, X. oryzae pv. oryzicola, and R. solani, respectively. Furthermore, $\mathbf{1}$ also exhibited moderate antibacterial activity against four fish pathogens, Edwardsiella tarda, Vibrio anguillarum, Aeromonas hydrophilia, and V.parahaemolyticus, with MIC values of 16, 8, 32, and $16 \mu \mathrm{g} / \mathrm{mL}$, respectively. Compounds 5, 9, and $\mathbf{1 0}$ showed antifungal activities with the MIC values of $25 \mu \mathrm{g} / \mathrm{mL}$ against $R$. solani. The results showed that $\mathbf{1}, \mathbf{5}, \mathbf{6}, \mathbf{9}, \mathbf{1 0}$, and 12 displayed moderate anti-inflammatory activity with $\mathrm{IC}_{50}$ values of $1.5,30.5,37.2,41.6,46.2$, and $34.3 \mu \mathrm{M}$, respectively, by measuring the inhibitory effects in P. acnes-induced THP-1 cells (Table 4).

Table 3. Antimicrobial activities of compounds 1-14 (MIC, $\mu \mathrm{g} / \mathrm{mL}$ ).

\begin{tabular}{cccccccccc}
\hline \multirow{2}{*}{ No. } & \multicolumn{9}{c}{ Bacteria } \\
\cline { 2 - 10 } & Xe & Xa & Et & Va & Ah & Vp & Rs & Fo & Cg \\
\hline $\mathbf{1}$ & 50 & 12.5 & 16 & 8 & 32 & 16 & 100 & $>100$ & $>100$ \\
$\mathbf{5}$ & $>100$ & $>100$ & - & - & - & - & 25 & $>100$ & $>100$ \\
$\mathbf{9}$ & $>100$ & $>100$ & - & - & - & - & 25 & $>100$ & $>100$ \\
$\mathbf{1 0}$ & $>100$ & $>100$ & - & - & - & - & 25 & $>100$ & $>100$ \\
Chloromycetin & 12.5 & 12.5 & 2 & 0.5 & 2 & 2 & - & - & - \\
Ketoconazole & - & - & - & - & - & - & 0.78 & 100 & 12.5 \\
\hline
\end{tabular}

Xe: Xanthomonas oryzae pv. oryzae; Xa: Xanthomonas oryzae pv. oryzicola; Et: Edwardsiella tarda; Va: Vibrio anguillarum; Ah: Aeromonas hydrophilia; Vp: Vibrio parahaemolyticus; Rs: Rhizoctonia solani; Fo: Fusarium oxysporum Cg: Colletotrichum gloeosporioides.

Table 4. Anti-inflammatory activities of tested compounds.

\begin{tabular}{cccc}
\hline \multirow{2}{*}{ No. } & \multicolumn{2}{c}{ THP-1 Cells } & P. acnes \\
\cline { 2 - 4 } & IC $_{\mathbf{5 0}}(\boldsymbol{\mu M})$ & SC $(\mu \mathbf{M})$ & MIC $(\mu \mathbf{M})$ \\
\hline $\mathbf{1}$ & $1.46 \pm 0.21$ & $0-5$ & $>5$ \\
$\mathbf{5}$ & $30.5 \pm 0.2$ & $0-40$ & $>40$ \\
$\mathbf{6}$ & $37.2 \pm 3.1$ & $0-50$ & $>50$ \\
$\mathbf{9}$ & $41.6 \pm 1.3$ & $0-50$ & $>50$ \\
$\mathbf{1 0}$ & $46.2 \pm 2.2$ & $0-50$ & $>50$ \\
$\mathbf{1 2}$ & $34.3 \pm 1.6$ & $0-50$ & $>50$ \\
Tretinoin & $3.38 \pm 0.28$ & $0-50$ & $>50$ \\
\hline
\end{tabular}

SC: Safe concentration, indicating the concentration range of THP-1 cells viability over $80 \%$ treated by tested compounds. 


\section{Materials and Methods}

\subsection{General Experimental Procedures}

Optical rotations were measured using a JASCO P-1020 polarimeter (JASCO Corporation, Tokyo, Japan) in $\mathrm{MeOH}$ at $25{ }^{\circ} \mathrm{C}$. UV spectra were recorded on a Shimadzu UV-1800 spectrophotometer (Shimadzu Corporation, Tokyo, Japan) in MeOH. ECD spectra were obtained by Chirascan circular dichroism spectrometers (Applied Photophysics Ltd., Leatherhead, UK). Both 1D and 2D NMR spectra were recorded on a Bruker AVIII-600 NMR spectrometer, using TMS as an internal standard. High-resolution electrospray ionization (HR-ESI-MS) was carried out with an Agilent 6529B Q-TOF instrument (Agilent Technologies, Santa Clara, CA, USA). Column chromatography was performed on silica gel (200-300 mesh, Qingdao Marine Chemical Inc., Qingdao, China) and ODS (50 $\mu \mathrm{m}, \mathrm{YMC}$, Kyoto, Japan) on a Flash Chromatograph System (SepaBen machine, Santai Technologies, Changzhou, China). Preparative high-performance liquid chromatography (Pre-HPLC) was performed on a Shimadzu LC-20 system (Shimadzu, Tokyo, Japan) equipped with a Shim-pack RP-C18 column $(20 \times 250 \mathrm{~mm}$ i.d., $10 \mu \mathrm{m}$, Shimadzu, Tokyo, Japan $)$ with a flow rate at $10 \mathrm{~mL} / \mathrm{min}$ at $25^{\circ} \mathrm{C}$.

\subsection{Fungal Material}

The fungal strain A. sp. YJ191021 was isolated from a soil sample, which was collected from the intertidal zone of Zhoushan, Zhejiang, China, in June 2018. The fungal strain was identified according to their morphological characteristics and by sequencing the fungal ITS region in rDNA. The fungal strain is stored in State Key Laboratory of Bioreactor Engineering laboratory of Shanghai at $-80^{\circ} \mathrm{C}$.

\subsection{Fermentation, Extraction, and Isolation}

The fungus was incubated on potato dextrose agar (PDA) medium at $28^{\circ} \mathrm{C}$ for 3 days. Then the grown strain was inoculated to a $250 \mathrm{~mL}$ Erlenmeyer flask containing $50 \mathrm{~mL}$ of potato dextrose broth (PDB). After 2 days of fermentation, the seed cultures were added to Erlenmeyer flasks $(100 \times 1000 \mathrm{~mL})$, each containing $100 \mathrm{~g}$ of dry rice and $120 \mathrm{~mL}$ of distilled water, which was previously sterilized at $121^{\circ} \mathrm{C}$ for $30 \mathrm{~min}$. All flasks were incubated at room temperature for 30 days. After incubation, whole fermented rice medium was extracted three times using ethyl acetate (EtOAc), and then solvents were concentrated under reduced pressure to give a crude extract (193.4 g). Next, the crude extract was subjected to a macroporous resin column eluting by a gradient $\mathrm{EtOH}-\mathrm{H}_{2} \mathrm{O}$ (from $30 \%$, $50 \%, 70 \%$ to $100 \% \mathrm{EtOH})$. The $50 \%$ fraction $(33.6 \mathrm{~g})$ was then separated on a silica gel column eluting with a stepwise gradient of $\mathrm{CH}_{2} \mathrm{Cl}_{2}-\mathrm{MeOH}$ (from 25:1 to 5:1) to yield five subfractions (A-E). Fraction D (4.3 g) was further purified by an ODS column $\left(\mathrm{MeCN}-\mathrm{H}_{2} \mathrm{O}\right.$, 35:65) and a semi-preparative HPLC eluting with $60 \% \mathrm{MeOH} / \mathrm{H}_{2} \mathrm{O}$ to yield compounds $\mathbf{1}\left(22.3 \mathrm{mg}, t_{\mathrm{R}} 30.4 \mathrm{~min}\right), \mathbf{1 4}\left(31.4 \mathrm{mg}, t_{\mathrm{R}} 10.4 \mathrm{~min}\right)$. Fraction C ( $\left.3.2 \mathrm{~g}\right)$ was further purified by an ODS column (MeCN- $\left.\mathrm{H}_{2} \mathrm{O}, 30: 70\right)$ and a semi-preparative HPLC eluting with $55 \%$ $\mathrm{MeOH} / \mathrm{H}_{2} \mathrm{O}$ to yield compounds $2\left(13.4 \mathrm{mg}, t_{\mathrm{R}} 34.2 \mathrm{~min}\right), 3\left(11.2 \mathrm{mg}, t_{\mathrm{R}} 30.6 \mathrm{~min}\right)$, and 4 $\left(9.2 \mathrm{mg}, t_{\mathrm{R}} 28.1 \mathrm{~min}\right)$. Fraction $\mathrm{B}(3.6 \mathrm{~g})$ was further purified by an ODS column $\left(\mathrm{MeCN}-\mathrm{H}_{2} \mathrm{O}\right.$, 40:60) and a semi-preparative HPLC eluting with $60 \% \mathrm{MeOH} / \mathrm{H}_{2} \mathrm{O}$ to yield compounds 6 $\left(16.7 \mathrm{mg}, t_{\mathrm{R}} 26.8 \mathrm{~min}\right), 7\left(4.2 \mathrm{mg}, t_{\mathrm{R}} 23.4 \mathrm{~min}\right)$, and $8\left(18.3 \mathrm{mg}, t_{\mathrm{R}} 19.3 \mathrm{~min}\right)$. The fraction $\mathrm{A}$ was separated on an ODS column $\left(\mathrm{MeCN}-\mathrm{H}_{2} \mathrm{O}, 55: 45\right)$ to yield four subfractions (A1-A4). The subfraction A3 was further purified by a semi-preparative HPLC eluting with 75\% $\mathrm{MeOH} / \mathrm{H}_{2} \mathrm{O}$ to yield compounds $5\left(6.4 \mathrm{mg}, t_{\mathrm{R}} 22.6 \mathrm{~min}\right), \mathbf{9}\left(12.3 \mathrm{mg}, t_{\mathrm{R}} 24.2 \mathrm{~min}\right)$, and $10\left(10.1 \mathrm{mg}, t_{\mathrm{R}} 25.6 \mathrm{~min}\right)$. The subfraction $\mathrm{A} 1$ was further purified by a semi-preparative HPLC eluting with $65 \% \mathrm{MeOH} / \mathrm{H}_{2} \mathrm{O}$ to yield compounds $11\left(8.4 \mathrm{mg}, t_{\mathrm{R}} 18.4 \mathrm{~min}\right), \mathbf{1 2}$ (7.3 mg, $\left.t_{\mathrm{R}} 16.2 \mathrm{~min}\right)$, and 13 (7.6 mg, $\left.t_{\mathrm{R}} 19.6 \mathrm{~min}\right)$.

Asperthrin A (1): Brilliant yellowish powder; $[\alpha]_{\mathrm{D}}^{25}-75.4(c 0.1, \mathrm{MeOH}) ; \mathrm{IR} v_{\max }$ 3448, 1708, 1409, 1368, 1192, $1123 \mathrm{~cm}^{-1}$; UV (MeOH) $\lambda_{\max }(\log \varepsilon) 217(4.00), 306$ (3.65) nm; ECD $(2.00 \mathrm{mM}, \mathrm{MeOH}) \lambda_{\max }(\Delta \varepsilon) 225(-4.33), 242(+0.70) \mathrm{nm} ;{ }^{1} \mathrm{H}$ and ${ }^{13} \mathrm{C}$ NMR data, see Tables 1 and 2; HRESIMS at $m / z$ 446.2071 [M + H] $]^{+}$(calcd. for $\mathrm{C}_{26} \mathrm{H}_{28} \mathrm{~N}_{3} \mathrm{O}_{4}, 446.2074$ ). 
Asperthrin B (2): White powder; $[\alpha]_{\mathrm{D}}^{25}-40.2$ (c 0.1, MeOH); IR $v_{\max } 3398,1693,1404$, $1117, \mathrm{~cm}^{-1}$; UV (MeOH) $\lambda_{\max }(\log \varepsilon) 203$ (4.05), 266 (3.70) nm; ECD (2.00 mM, MeOH) $\lambda_{\max }$ $(\Delta \varepsilon) 224(-4.63), 242(+0.77) \mathrm{nm} ;{ }^{1} \mathrm{H}$ and ${ }^{13} \mathrm{C}$ NMR data, see Tables 1 and 2; HRESIMS at $m / z 486.2002[\mathrm{M}+\mathrm{Na}]^{+}$(calcd. for $\mathrm{C}_{26} \mathrm{H}_{29} \mathrm{~N}_{3} \mathrm{O}_{5} \mathrm{Na}, 486.1999$ ).

Asperthrin C (3): White powder; $[\alpha]_{\mathrm{D}}^{25}+16.6$ (c 0.1, MeOH); IR $v_{\max } 3417,2983,1689$, 1538, 1496, $1121 \mathrm{~cm}^{-1}$; UV (MeOH) $\lambda_{\max }(\log \varepsilon) 203$ (4.10), 267 (3.74) nm; ECD (2.00 mM, $\mathrm{MeOH}) \lambda_{\max }(\Delta \varepsilon) 224(-4.63), 242(+2.23) \mathrm{nm} ;{ }^{1} \mathrm{H}$ and ${ }^{13} \mathrm{C}$ NMR data, see Tables 1 and 2; HRESIMS at $m / z 516.2102[\mathrm{M}+\mathrm{Na}]^{+}$(calcd. for $\mathrm{C}_{27} \mathrm{H}_{31} \mathrm{~N}_{3} \mathrm{O}_{6} \mathrm{Na}, 516.2105$ ).

Asperthrin D (4): White powder; $[\alpha]_{\mathrm{D}}^{25}+32.2$ ( $\left.0.1, \mathrm{MeOH}\right) ; \mathrm{IR} v_{\max } 3428,2934,1695$, 1490, $1112 \mathrm{~cm}^{-1}$; UV (MeOH) $\lambda_{\max }(\log \varepsilon) 206$ (4.09), 267 (3.76) nm; ECD (2.00 mM, MeOH) $\lambda_{\max }(\Delta \varepsilon) 225(+4.21), 242(-1.79) \mathrm{nm} ;{ }^{1} \mathrm{H}$ and ${ }^{13} \mathrm{C}$ NMR data, see Tables 1 and 2; HRESIMS at $m / z$ 516.2106 [M + H] $]^{+}$(calcd. for $\mathrm{C}_{27} \mathrm{H}_{31} \mathrm{~N}_{3} \mathrm{O}_{6} \mathrm{Na}$, 516.2105).

Asperthrin E (5): White powder; $[\alpha]_{\mathrm{D}}^{25}+53.4$ (c 0.1, MeOH); IR $v_{\max } 3437,2981,1696$, 1463, $1123 \mathrm{~cm}^{-1}$; UV (MeOH) $\lambda_{\max }(\log \varepsilon) 203$ (3.96), 247 (4.03) nm; ECD (2.00 mM, MeOH) $\lambda_{\max }(\Delta \varepsilon) 236(+4.17), 253(-2.16) \mathrm{nm} ;{ }^{1} \mathrm{H}$ and ${ }^{13} \mathrm{C}$ NMR data, see Tables 1 and 2; HRESIMS at $m / z 528.2102[\mathrm{M}+\mathrm{Na}]^{+}$(calcd. for $\mathrm{C}_{28} \mathrm{H}_{31} \mathrm{~N}_{3} \mathrm{O}_{6} \mathrm{Na}$, 528.2105).

Asperthrin F (6): White powder; $[\alpha]_{\mathrm{D}}^{25}-157.4$ (c 0.1, MeOH); IR $v_{\max } 3498,2980$, $1689,1418,1072 \mathrm{~cm}^{-1} ; \mathrm{UV}(\mathrm{MeOH}) \lambda_{\max }(\log \varepsilon) 237$ (4.16), 288 (3.64), 338 (3.50) nm; ECD $(2.00 \mathrm{mM}, \mathrm{MeOH}) \lambda_{\max }(\Delta \varepsilon) 226(-4.68), 241(-2.26) \mathrm{nm}, 257(-4.94) ;{ }^{1} \mathrm{H}$ and ${ }^{13} \mathrm{C} \mathrm{NMR}$ data, see Tables 1 and 2; HRESIMS at $m / z 504.2103[\mathrm{M}+\mathrm{Na}]^{+}$(calcd. for $\mathrm{C}_{26} \mathrm{H}_{31} \mathrm{~N}_{3} \mathrm{O}_{6} \mathrm{Na}$, 504.2105).

\subsection{Antimicrobial Assays}

Minimum Inhibitory Concentration (MIC) assays were used to assess antimicrobial activities of all isolated compounds against two agricultural pathogenic bacteria (Xanthomonas oryzae pv. oryzae and Xanthomonas oryzae pv. oryzicola) and three agricultural fungi (Colletotrichum gloeosporioides penz, Fusarium oxysporum and Rhizoctonia solani). Furthermore, Compound $\mathbf{1}$ was tested for antibacterial activities against four fish pathogens, Edwardsiella tarda, Vibrio anguillarum, Aeromonas hydrophilia, and Vibrio parahaemolyticus. Chloromycetin was used as a positive antibacterial control and ketoconazole was used as a positive antifungal control. The experimental procedure is detailed in the Supporting Information (SI). All the experiments were performed in three independent replicates.

\subsection{Anti-Inflammatory Assays}

The human monocyte cell line THP-1 (Cell Bank of China Science Academy, Shanghai, China) and Propionibacterium acnes (ATCC6919, Xiangfu biotech, Shanghai, China) were used in anti-inflammatory experiments. The P. acnes in logarithmic growth phase was used to induce inflammation in THP-1 cells. MTT method was carried out for tested compounds to determine their safe concentration to THP-1 cells. Besides, antimicrobial assays were performed to exclude false anti-inflammatory activity of these compounds raised from their inhibition to $P$. acnes. The inhibitory activity of the test compounds on the secretion of inflammatory factor $1 \mathrm{~L}-1 \beta$ by THP-1 cells was assayed by ELISA experiment $[24,25]$. The experimental procedure is detailed in the SI. All the experiments were performed in three independent replicates.

\section{Conclusions}

In summary, six new prenylated indole diketopiperazine alkaloids, asperthrins A-F (1-6), along with eight known analogues (7-14), were isolated from the solid rice cultures of the marine-derived fungus Aspergillus sp. YJ191021. Asperthrin A (1) showed potent anti-bacterial, anti-fungal, and anti-inflammatory activities at micromolar level. These results expand the chemical diversity of prenylated indole alkaloids and provide a basis for further development of prenylated indole alkaloids into natural agrochemicals and drug leads. 
Supplementary Materials: The following are available online at https:/ /www.mdpi.com/1660-339 7/19/3/157/s1, Figures S1-S54: ${ }^{1} \mathrm{H},{ }^{13}$ C, HSQC, HMBC, ROESY, UV, IR, ECD, and HRESIMS spectra of the new compounds 1-6, Tables S1-S6: Computational data of $\mathbf{1}$ and $\mathbf{4}$.

Author Contributions: J.Y., Y.D., and Z.W. performed the isolation, purification, and identification of all compounds. L.G. and Y.J. tested the anti-inflammatory activities, and supervised the laboratory work. M.G. and X.X. edited the manuscript. F.A. supervised the laboratory work, designed the experiments, and edited the manuscript. All authors have read and agreed to the published version of the manuscript.

Funding: This work was funded by the National Key R\&D Program of China (2018YFC1706206, 2019YFC0312504), and the National Natural Science Foundation of China (41876189, 81703388). This work was also supported by State Key Laboratory of Bioreactor Engineering and the Open Research Fund Program of Institute of regulatory science, Beijing Technology and Business University (CRS2020-02), the Open Research Fund Program of Key Laboratory of Cosmetic (Beijing Technology and Business University), China National Light Industry (KLC-2019-ZD2).

Acknowledgments: Authors thank Wei Wang (State Key Laboratory of Bioreactor Engineering, East China University of Science and Technology) for proving X. oryzae pv. oryzae, X. oryzae pv. oryzicola, and R. solani.

Conflicts of Interest: The authors declare no conflict of interest.

\section{References}

1. Zhou, Z.X.; Wei, D.F.; Lu, Y.H. Polyhexamethylene guanidine hydrochloride shows bactericidal advantages over chlorhexidine digluconate against ESKAPE bacteria. Biotechnol. Appl. Bioc. 2015, 62, 268-274. [CrossRef]

2. Wang, J.; Yao, L.Y.; Lu, Y.H. Ceriporia lacerata DMC1106, a new endophytic fungus: Isolation, identification, and optimal medium for 2', 4'-dihydroxy-6'-methoxy-3',5'-dimethylchalcone production. Biotechnol. Bioproc. Eng. 2013, 18, 669-678. [CrossRef]

3. Farooq, S.; Qayum, A.; Nalli, Y.; Lauro, G.; Chini, M.G.; Bifulco, G.; Chaubey, A.; Singh, S.K.; Riyaz-Ul-Hassan, S.; Ali, A. Discovery of a Secalonic Acid Derivative from Aspergillus aculeatus, an Endophyte of Rosa damascena Mill., Triggers Apoptosis in MDA-MB-231 Triple Negative Breast Cancer Cells. ACS Omega 2020, 5, 24296-24310. [CrossRef] [PubMed]

4. Zhao, D.L.; Han, X.B.; Wang, M.; Zeng, Y.T.; Li, Y.Q.; Ma, G.Y.; Liu, J.; Zheng, C.J.; Wen, M.X.; Zhang, Z.F.; et al. Herbicidal and Antifungal Xanthone Derivatives from the Alga-Derived Fungus Aspergillus versicolor D5. J. Agric. Food Chem. 2020, 68, 11207-11214. [CrossRef] [PubMed]

5. Peyrat, L.A.; Eparvier, V.; Eydoux, C.; Guillemot, J.C.; Litaudon, M.; Stien, D. Carneic Acids from an Endophytic Phomopsis sp. as Dengue Virus Polymerase Inhibitors. J. Nat. Prod. 2020, 83, 2330-2336. [CrossRef] [PubMed]

6. Yuan, X.L.; Wang, X.F.; Xu, K.; Li, W.; Chen, D.; Zhang, P. Characterization of a New Insecticidal Anthraquinone Derivative from an Endophyte of Acremonium vitellinum against Helicoverpa armigera. J. Agric. Food Chem. 2020, 68, 11480-11487. [CrossRef] [PubMed]

7. Liu, W.H.; Ding, Y.; Ji, X.; An, F.L.; Lu, Y.H. Curvulaide A, a bicyclic polyketide with anti-anaerobic bacteria activity from marine-derived Curvularia sp.. J. Antibiot. 2018, 72, 111-113. [CrossRef] [PubMed]

8. Ding, Y.; Zhu, X.; Hao, L.; Zhao, M.; Hua, Q.; An, F. Bioactive Indolyl Diketopiperazines from the Marine Derived Endophytic Aspergillus versicolor DY180635. Mar. Drugs 2020, 18, 338. [CrossRef]

9. Han, W.B.; Lu, Y.H.; Zhang, A.H.; Zhang, G.F.; Mei, Y.N.; Jiang, N.; Lei, X.; Song, Y.C.; Ng, S.W.; Tan, R.X. Curvulamine, a New Antibacterial Alkaloid Incorporating Two Undescribed Units from a Curvularia Species. Org. Lett. 2014, 16, 5366-5369. [CrossRef]

10. Borthwick, A.D. 2,5-Diketopiperazines: Synthesis, Reactions, Medicinal Chemistry, and Bioactive Natural Products. Chem. Rev. 2012, 112, 3641-3716. [CrossRef]

11. Ma, Y.M.; Liang, X.A.; Kong, Y.; Jia, B. Structural Diversity and Biological Activities of Indole Diketopiperazine Alkaloids from Fungi. J. Agric. Food Chem. 2016, 64, 6659-6671. [CrossRef]

12. Li, H.; Xu, D.; Sun, W.; Yang, B.; Li, F.; Liu, M.; Wang, J.; Xue, Y.; Hu, Z.; Zhang, Y. HPLC-DAD-Directed Isolation of Linearly Fused Prenylated Indole Alkaloids from a Soil-Derived Aspergillus versicolor. J. Nat. Prod. 2019, 82, 2181-2188. [CrossRef]

13. Levinson, A.M. Total Synthesis of Aspeverin via an Iodine(III)-Mediated Oxidative Cyclization. Org. Lett. 2014, 16, 4904-4907. [CrossRef]

14. Zhang, P.; Yuan, X.L.; Du, Y.M.; Zhang, H.B.; Shen, G.M.; Zhang, Z.F.; Liang, Y.J.; Zhao, D.-L.; Xu, K. Angularly Prenylated Indole Alkaloids with Antimicrobial and Insecticidal Activities from an Endophytic Fungus Fusarium sambucinum TE-6L. J. Agric. Food Chem. 2019, 67, 11994-12001. [CrossRef] [PubMed]

15. He, W.; Xu, Y.; Fu, P.; Zuo, M.; Liu, W.; Jiang, Y.; Wang, L.; Zhu, W. Cytotoxic Indolyl Diketopiperazines from the Aspergillus sp . GZWMJZ-258, Endophytic with the Medicinal and Edible Plant Garcinia multiflora. J. Agric. Food Chem. 2019, 67, 10660-10666. [CrossRef] [PubMed]

16. Whyte, A.C.; Gloer, J.B.; Wicklow, D.T.; Dowd, P.F. Sclerotiamide: A New Member of the Paraherquamide Class with Potent Antiinsectan Activity from the Sclerotia of Aspergillus sclerotiorum. J. Nat. Prod. 1996, 59, 1093-1095. [CrossRef] [PubMed] 
17. Tsukamoto, S.; Kato, H.; Samizo, M.; Nojiri, Y.; Onuki, H.; Hirota, H.; Ohta, T. Notoamides F-K, Prenylated Indole Alkaloids Isolated from a Marine-Derived Aspergillus sp. J. Nat. Prod. 2008, 71, 2064-2067. [CrossRef]

18. Cai, S.X.; Luan, Y.P.; Kong, X.L.; Zhu, T.J.; Gu, Q.Q.; Li, D.H. Isolation and Photoinduced Conversion of 6-epi-Stephacidins from Aspergillus taichungensis. Org. Lett. 2013, 15, 2168-2171. [CrossRef] [PubMed]

19. Tsukamoto, S.; Umaoka, H.; Yoshikawa, K.; Ikeda, T.; Hirota, H. Notoamide O, a Structurally Unprecedented Prenylated Indole Alkaloid, and Notoamides P-R from a Marine-Derived Fungus, Aspergillus sp. J. Nat. Prod. 2010, 73, 1438-1440. [CrossRef] [PubMed]

20. Sugimoto, K.; Sadahiro, Y.; Kagiyama, I.; Kato, H.; Sherman, D.H.; Williams, R.M.; Tsukamoto, S. Isolation of amoenamide A and five antipodal prenylated alkaloids from Aspergillus amoenus NRRL 35600. Tetrahedron Lett. 2017, 58, 2797-2800. [CrossRef]

21. Kato, H.; Yoshida, T.; Tokue, T.; Nojiri, Y.; Hirota, H.; Ohta, T.; Williams, R.M.; Tsukamoto, S. Notoamides A-D: Prenylated Indole Alkaloids Isolated from a Marine-Derived Fungus, Aspergillus sp. Angew. Chem. Int. Ed. 2007, 46, 2254-2256. [CrossRef]

22. Qian, J.; Wu, J.Y.; Yao, B.B.; Lu, Y.H. Preparation of a polyclonal antibody against hypericin synthase and localization of the enzyme in red-pigmented Hypericum perforatum L. plantlets. Acta Biochim. Pol. 2012, 59, 639-645. [CrossRef] [PubMed]

23. Afiyatullov, S.S.; Zhuravleva, O.I.; Antonov, A.S.; Berdyshev, D.V.; Pivkin, M.V.; Denisenko, V.A.; Popov, R.S.; Gerasimenko, A.V.; von Amsberg, G.; Dyshlovoy, S.A.; et al. Prenylated indole alkaloids from co-culture of marine-derived fungi Aspergillus sulphureus and Isaria felina. J. Antibiot. 2018, 71, 846-853. [CrossRef] [PubMed]

24. Guo, M.M.; An, F.L.; Wei, X.; Hong, M.H.; Lu, Y.H. Comparative Effects of Schisandrin A, B, and C on Acne-Related Inflammation. Inflammation 2017, 40, 2163-2172. [CrossRef] [PubMed]

25. An, F.L.; Wang, X.B.; Yang, M.H.; Luo, J.; Kong, L. Bioactive A-ring rearranged limonoids from the root barks of Walsura robusta. Acta Pharm. Sin. B 2019, 9, 545-556. [CrossRef] 